\title{
Regency Of Indonesia
}

Muhammad Hajar Dewantoro ${ }^{1 *}$, Junanah², Mohamad Joko Susilo ${ }^{3}$

1,2,3 Universitas Islam Indonesia, Indonesia

\begin{tabular}{|c|c|}
\hline ARTICLE INFO & ABSTRACT \\
\hline $\begin{array}{l}\text { Article History } \\
\text { Received : Apr 15, } 2018 \\
1^{\text {st }} \text { Revision : Oct 19, } 2018 \\
\text { Accepted : Apr 15, } 2020 \\
\text { Available Online : Jun 28, } 2021 \\
\text { Keywords: } \\
\text { independence } \\
\text { level } \\
\text { muhammadiyah } \\
\text { school autonomy } \\
\text { *Corresponding Author } \\
\text { Email address: } \\
\text { hajar.dewantoro@uii.ac.id }\end{array}$ & $\begin{array}{l}\text { School autonomy gives schools authority without any intervention from other parties, } \\
\text { ranging from management to the curriculum, facilities and infrastructure, financing, } \\
\text { implementation of the teaching and learning process, teachers and staff, and } \\
\text { assessment. Therefore, schools are able to make innovations in the development of } \\
\text { school branding, making them a top community choice. This study aims to assess the } \\
\text { level of school autonomy, especially in Muhammadiyah schools. A survey was } \\
\text { employed using the LCBT evaluation instrument model. The subject was } \\
\text { Muhammadiyah Junior High Schools in Sleman Region, including } 254 \text { individuals } \\
\text { consisting of four principals, } 115 \text { teachers and staff, and } 135 \text { grade } 8 \text { and } 9 \text { students. } \\
\text { The data collection technique involved questionnaires, interviews, and } \\
\text { documentation, while analysis was based on qualitative and quantitative descriptive } \\
\text { techniques. The results of the study show that SMP Muhammadiyah } 1 \text { Gamping had } \\
\text { an autonomy score of } 365.30 \text { in the strong category; SMP Muhammadiyah } 1 \text { Minggir } \\
\text { had an autonomy score of } 394.58 \text { in the very strong category; SMP Muhammadiyah } \\
2 \text { Kalasan had an autonomy score of } 354.56 \text { in the strong category; and SMP } \\
\text { Muhammadiyah } 3 \text { Depok had an autonomy score of } 364.66 \text { also in the strong } \\
\text { category. It can be concluded that all the schools are autonomous, as demonstrated } \\
\text { by the branding of each; their outstanding achievements; a school culture that has } \\
\text { been ingrained into the heart of the whole school community; and high public } \\
\text { interest. }\end{array}$ \\
\hline
\end{tabular}

How to cite: Dewantoro, M. H., Junanah, Susilo, M. J. (2021). The Level Of Autonomy Of Muhammadiyah Junior High Schools In Sleman Regency Of Indonesia. International Journal of Pedagogy and Teacher Education, 5(1), 42-49.

\section{INTRODUCTION}

Nowdays, the era of globalisation signals the importance of increasing school autonomy and the competitiveness of states. Autonomy is a form of school effectiveness and improvement; with it schools are able to optimise the achievement of educational goals, their potential, and school resources. The implementation of learning emphasises the development of potential learners in order to produce qualified graduates.

In the management of education, Susilo (2017c) states that in order to be autonomous, schools need to excel in school management, curriculum development, the improvisation of learning methods, improvements in evaluation, the procurement of educators and staff, budgeting, facilities and infrastructure, academic quality, and autonomy in the culture of quality. Therefore, the management of such education should be addressed immediately, as it involves its rapid growth and competitiveness with other schools.

The growth of education is influenced by the managerial ability to manage the external environment, other competitor institutions, and internal competence. Therefore, educational institutions should be able to create a viable strategy to excel against the competition without abandoning the essence of education itself (Irianto, 2015:201-2). Schools that want to do this must be able to build their brand image in the community (Triwiyanto, 2015). This can be formed of various factors, such as institutional accreditation, ISO, student behaviour, achievement, graduate quality, excellence in activities, and alumni relations (Rukmana, 2016).

Building a brand image is not an easy task. Schools must be able to recognise their potential and relate it to the demands of globalisation. Success in linking these two aspects will give birth to excellent programmes, which will ultimately be able to improve the school image (Triwiyanto, 2015). Such programmes are the foundation of school autonomy, which itself is a pre-requisite for school improvement (Caldwell 2016:34). School autonomy is also regarded largely as a tool to be used to improve the quality of education (Eurydice, 2007). 
Autonomy is the result of a strong internal effort by the school to manage itself independently in order to realise its ideals. As stated by Susilo (2017), school autonomy involves the ability of schools to manage and develop themselves independently, so have a distinct advantage and are different from other schools. Scileanna $(2015$, p. 4) states that school autonomy is a tool used to improve the quality of education. In same way, the Department of Education and Skills (2015) states that school autonomy involves the freeing up of schools from centralised and bureaucratic control or, put simply, the decentralisation of decision-making to schools. Nevertheless, Caldwell $(2014$, p. 3) argues that the concept of school autonomy cannot be explained in detail. It is misleading, because schools in a public education system cannot be fully autonomous. It is better to refer to a relatively high or relatively low level of autonomy, being careful to specify the functions over which schools have secured more authority and responsibility.

School autonomy has several levels. PISA (Programme for International Student Assessment) categorises it into three groups: 1) schools with relatively high levels of autonomy, which have enjoy more competitiveness and the freedom to choose appropriate learning methods, and are free to manage and develop themselves; 2) schools with high levels of autonomy, but low competitiveness - despite having the authority to make policies, schools in this category have low public interest; and 3) schools with relatively low levels of autonomy, but with a high incentive to compete with other schools (OEDC, 2014:71).

Schools with a stronger level of autonomy will know better how to prepare their students, how to develop institutions that support their vision, and how to manage staff, teachers and manage financing. In line with Susilo (2017), the characteristics of schools that already have strong autonomy will be established: public confidence with evidence of student interest; habits that shape a positive, innovative, and dynamic culture in a good work environment; internal and external support units; a curriculum that has positive values; an innovative learningorientation in progress and independence; independent funding sources; and school achievements at international, national, regional, and local levels. According to Cheng and Ming (1997), schools with strong autonomy are more likely to be able to make their own educational changes through student achievement in learning.

The aims of increasing autonomy vary. According to Eurydice (2007), 1) schools will function better if they are autonomous and accountable; 2 ) those closest to the school know how best to serve the students; and 3) schools that are in difficulty will improve if they have the flexibility to make changes to their teachers or staff. School autonomy is also important in empowering schools to take more ownership of decision making and assume appropriate levels of accountability. By embracing school autonomy, school districts move closer to achieving their goals and enable local schools to create customised educational experiences for their students (Fulton County Schools, 2014:5).

The policy on school independence has been in effect since 2005 in formal schools in Indonesia, no except muhammadiyah schools. Muhammadiyah is a large Islamic organization in Indonesia, even in various countries. This organization became the Islamic da'wah movement amar ma'ruf nahi munkar (inviting goodness and preventing evil) and tajdid (renewal on the main teachings of Islam) which are based on the Qur'an and as-Sunnah as-Sohihah. Muhammadiyah organizations have business charities, both in the fields of social activities, health, and education. Particularly in Muhammadiyah schools, school autonomy began to be rolled out after the congress in Malang in 2005 (Muhammadiyah Yogyakarta Regional Leadership Council for Primary and Secondary Education, 2015:337). Since then, the goals of Muhammadiyah education have been to form excellent schools; achieve independence and global competitiveness; have a culture of continuous quality and support from stakeholders; implement the values of Islam and Kemuhammadiyahan; be oriented to create future generations who are cautious, excellent, have a good temprament (akhlaqul karimah), and are independent; and the missionary purpose amar ma'ruf nahi munkar (Kabargersik.com, 2017; Musdani, 2017; Ratnawati, 2016; Susilo, 2017d).

To date, Muhammadiyah schools have not been measured for their level of autonomy. The classification of schools is still limited to category ranking: 1) high grade for schools that are considered to be independent or community-chosen; 2) middle class or those in a developing state; and 3) lower class for undeveloped or underserved schools (Solopos 2017). However, schools are actively promoting their brand image, increasing their level of autonomy and excellence (Kabargersik.com, 2017; Lusiana, 2015; Musdani, 2017; Nursalikah and Rini, 2013). The Elementary School of Muhammadiyah Sapen established a business entity belonging to the school in the field of catering with SBM (Sapen Boga Mandiri), and one year earlier successfully opened a confection service (SD Muhammadiyah Sapen, 2017). Examples of the brand image of schools include the Disaster Preparedness 
School (Sekolah Siaga Bencana/SSB) (MC Provinsi Jawa Timur, 2018; Suaramuhammadiyah.id, 2016); the Sunday school (SMP Muhammadiyah 2 Surabaya, 2018); and the memorizing/tahfidz Al Qur'an school (Bangka Pos, 2017).

Measuring the level of school autonomy can be used as the basis for establishing future school development policy. The direction of school development will be formally written as a roadmap designed in the school's strategic plan, so that there will be no programme repetition in its development, other than regular programmes. Consequently, schools can be more focused on achieving the advantages that have been declared in the strategic plan. Given that school autonomy is part of the determinants of school quality, it is necessary to know the level of autonomy. This study therefore aims to measure the level of Muhammadiyah school autonomy, especially in Sleman, Yogyakarta, Indonesia on Junior High School.

\section{MATERIAL AND METHODS}

The research comprised a survey aimed at assessing Muhammadiyah school autonomy at the Junior High School level in Sleman Regency. The data collection instrument used was the LCBT evaluation instrument model of Susilo (2017). The research subjects consisted of 254 individuals: four principals, 115 teachers and staff, and 135 grade 8 and 9 students. The research objects were SMP Muhammadiyah 1 Gamping, SMP Muhammadiyah 1 Minggir, SMP Muhammadiyah 2 Kalasan, and SMP Muhammadiyah 3 Depok. To supplement the data, interviews were conducted with the principal, teachers, and staff and documentation obtained on each school. Data analysis was made using qualitative and quantitative descriptive techniques.

Through the LCBT evaluation instrument developed by Susilo (2017a), Muhammadiyah school autonomy at the junior high school level was measured based on four main components: leadership (L), culture (C), backing (B), and transactional (T). Furthermore, the scores on school autonomy were divided into five categories: very strong, strong, moderate, weak, and very weak.

\section{RESULTS AND DISCUSSION}

The data were analysed, with the results shown in Table 1.

Table 1. Influence each component of school autonomy

\begin{tabular}{|c|c|c|c|c|c|c|c|c|c|c|c|c|}
\hline \multirow{2}{*}{ School } & \multirow{2}{*}{ Subjects } & \multirow{2}{*}{$\sum \mathrm{L}$} & \multirow{2}{*}{$\% \mathrm{~L}$} & \multirow{2}{*}{$\Sigma C$} & \multirow{2}{*}{$\% \mathrm{C}$} & \multirow{2}{*}{$\sum \mathrm{B}$} & \multirow{2}{*}{$\% \mathrm{~B}$} & \multirow{2}{*}{$\sum T$} & \multirow{2}{*}{$\% \mathrm{~T}$} & \multicolumn{3}{|c|}{ Autonomy } \\
\hline & & & & & & & & & & Score & $\%$ & Category \\
\hline SMP M 1 Gamping & 66 & 54.97 & 12 & 52.48 & 11 & 79.24 & 17 & 178.61 & 38 & 365.30 & 79 & Strong \\
\hline SMP M 3 Depok & 56 & 53.89 & 12 & 50.39 & 11 & 78.50 & 17 & 181.88 & 39 & 364.66 & 78 & Strong \\
\hline SMP M 2 Kalasan & 66 & 55.44 & 12 & 50.70 & 11 & 76.95 & 17 & 171.47 & 37 & 354.56 & 76 & Strong \\
\hline SMP M 1 Minggir & 66 & 60.53 & 13 & 56.53 & 12 & 84.61 & 18 & 192.91 & 41 & 394.58 & 85 & Very Strong \\
\hline
\end{tabular}

The results show that SMP Muhammadiyah 1 Gamping had an autonomy score of 365.30 in the strong category; SMP Muhammadiyah 3 Depok had an autonomy score of 364.66 in the strong category; SMP Muhammadiyah 2 Kalasan had an autonomy score of 354.56 in the strong category, and SMP Muhammadiyah 1 Minggir had an autonomy score of 394.58 in the very strong category. The percentages of school autonomy are shown in Figure 1.

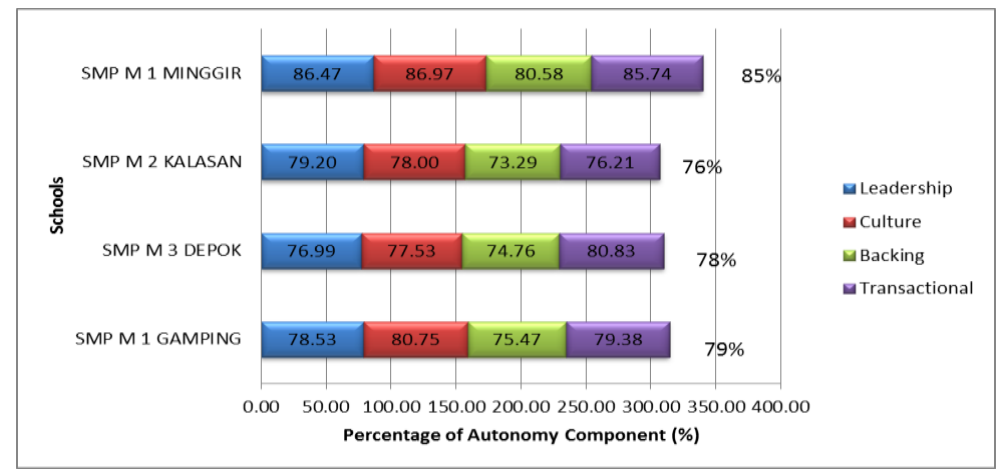

Fig 1. Total Autonomy Level Scores

Figure 1 shows that SMP Muhammadiyah 1 Minggir had the highest autonomy level, with a percentage score of $85 \%$. The level in the others schools was around $76 \%-79 \%$. The total autonomy level scores are based 
on the score of each component of school autonomy: leadership (L), culture (C), backing (B), and transactional (T). From each LCBT component in Figure 1, it can be seen that the highest score is SMP 1 Minggir, in the range of 80.58 - 86.97, while the other three schools ranged between 74.76 and 80.83 . The results show that Muhammadiyah Junior High School 1 Minggir has a very strong level of autonomy compared to the other three schools. Nevertheless, the difference in the level of autonomy is relatively small.

From the data, school implementation can be identified through the autonomy components, based on the school autonomy criteria of Susilo (2017a, p. 10), as detailed below.

\begin{tabular}{ll} 
Table 2. Category of school autonomy \\
\hline \multicolumn{1}{c}{ Autonomy Score } & \multicolumn{1}{c}{ Category } \\
\hline $373<\chi<465$ & Very Strong \\
$280<\chi<372$ & Strong \\
$187<\chi<279$ & Moderate \\
$93<\chi<186$ & Weak \\
$0<\chi<93$ & Very Weak \\
\hline \multicolumn{2}{r}{ Source: Susilo (2017b). }
\end{tabular}

\section{Leadership}

In terms of leadership, schools with a very strong level of autonomy have principals who are able to manage and develop the school, so the characteristics of its superiority are more evident than in other schools. In schools with a strong level of autonomy, the principals are able to manage and conduct school development, but limited to the normative standards set. This is what distinguishes the very strong and strong levels of autonomy. Effective policy-making is only achieved after principals have analysed the potential of their school carefully and thoroughly, so that their self-evaluation in fact reflects their school's strengths, weaknesses, opportunities, and threats. An example of a school that has a strong level of independence is SMP Muhammadiyah 1 Minggir.

The most prominent aspect of SMP Muhammadiyah 1 Minggir began with the courage of the headmaster in developing a policy for the procurement of a school bus. This was based on a thorough analysis of the geographic conditions of the school, which is located in aborder area between Central Java and the Special Region of Yogyakarta (DIY/Daerah Istimewa Yogyakarta). The policy was supported by school residents, school committees and colleagues at the branch level. Based on interviews with the school principals, school buses are used for school purposes, such as student pick-ups, tours, and other school activities. As a result, the efforts made earned the trust of the community, so that in the following year students' interest in entering SMP M 1 Minggir increased significantly. The right policy is able to create a comfortable working atmosphere, so blessings flow abundantly in the school. In addition, other policies include scholarships to students, teachers, and employees who excel.

As reported by Hamilton Associates (2015, p. 12), when principals have autonomy, this creates an empowered mindset and the capacity to use it to produce benefits for all the school's academic community. Such policy-making gives the power to improve schools.

In general, Muhammadiyah schools have virtually the same characteristics as other schools that organise programmes; for example: a custodial programme to recruit new learners; a reward programme to improve students' achievement motivation; collaboration with various agencies; and excellent school programmes, such as disaster mitigation schools, adiwiyata schools, tahfidz schools, etc.

\section{Culture}

In term of culture, schools with a strong level of autonomy have an independent culture; harmonious relationships amongst the school community; intimate school relationships; a high sense of togetherness; a good performance atmosphere; prosperity and high achievement motivation. At the same time, schools with a strong level of autonomy still often appear 'click/conflict' in the organization; friendly relations between school members, with a sense of togetherness; atmosphere performance is not consistent (meaning that at any time the individual can appear laziness, feel uncomfortable, work mood decreases, sometimes the intention is to remain, feel excited to work again, comfortable, etc., which is mostly caused by factors such as amount of income, employment status, promotion, etc.); less well-being (meaning that income is not in line with the amount of work, for example too much work without being balanced with a large wage), but achievement motivation is relatively high.

A Using SMP Muhammadiyah 1 Minggir as an illustration, the new policy of school bus procurement had an impact on the positive work atmosphere of school member. Cultures help each other and help to realise the 
expectations of the school. Every member of the school has empathy and sincerity in loving his school. This kind of culture can be demonstrated by the willingness and sincerity of school members to temporarily lend land to the school (complete with land certificates) for the school to use properly. This proves a sense of handarbeni (belonging) to the school. The whole school community considers that the school is part of a family, meaning a fabric of harmonious relations and intimacy can really be felt at SMP Muhammadiyah 1 Minggir. All the members of school have announced to achieve one goal, namely to become a superior school in the hearts of the community with a myriad of achievements.

The ilustration of SMP Muhammadiyah 1 Minggir, according to Zamroni (2016, p. 55), belongs to the category of a familiar dynamic culture or a hothouse culture (Hargreaves, 1995; Harris, 2005), in which there are very warm and friendly fellow school member. The interactions are human, warm, informal, and meaningful. Motivation for student achievement is also high; teachers want the best for their students, which will produce a culture that encourages school member to make high achievements. As shown by Macneil, Prater, and Busch (2009), students achieve higher scores on standardised tests in schools with a healthy learning environment.

In general, Muhammadiyah school culture includes the performance of ceremonies every Monday and the commemoration of ceremonies on national days; the rotation of ceremonial officers; the carrying out of picket (class cleaning schedule); community service in school; the collection of students' Handphone before starting lessons; welcoming students every morning; performing Qur'anic tadarus every ten minutes before the first lesson begins in everyday; praying in congregation dhuhur and jum'at; collecting infaq every Friday from all the school member; and providing compensation when students are affected by disasters (Susiloz, 2017b).

\section{Backing}

In term of school support, schools with a very strong level of autonomy have extensive partnerships, including in the international sphere. Partnerships can involve bureaucrats, academics, business and industry, and have strong internal support from friendly relations between school members. As stated by Caldwell (2014, p. 37), a very strong level of autonomy provides a school and its staff with more degrees of freedom to innovate, but this depends on them having the necessary capacities, a willingness to take risks, and a professional environment in which these aspects are not unduly constrained by accountability requirements or time limitations. Schools with a strong level of autonomy have a network of partnerships on a national scale, as well as internal support from committees and school residents.

The state of school autonomy at SMP Muhammadiyah 1 Minggir is first shown by the extraordinary internal support from the school community. After one year has passed, external support for the school began to be given by persyarikatan/the association, academics, bureaucracy, and the wider community. The opportunities for schools to become partners with institutions, organizations, academics, etc. through the signing of a Memorandum of Understanding. The existence of full support from various parties (committee, parents, community, etc.) gives Muhammadiyah schools autonomy in funding.

In Muhammadiyah schools, the main source of funding support comes from students, even though some is from government/foundations. Moreover, most schools have BUMS (School Owned Enterprises), which result in more stable schools in terms of funding issues. Funding management is also transparent and accountable, using a financial management system with four principles of prosperity: schools, teachers, employees, and guardians. In addition, there is strong internal school member academic support, good IT capability, strong external support (committees, community, parents, $\geq 60 \%$ support learning by the credit system (SKS), and support from assemblies, consultants, and colleges). Muhammadiyah school facilities are also widely established on waqf land (wakaf) that have been submitted to persyarikatan. In terms of completeness of facilities, Muhammadiyah schools are more dominant in procuring school facilities independently without relying on donors, so they can have educational support and support facilities that are much more adequate when compared to other schools (which still depend on donors). Naturally, the criteria and requirements that suit the needs of the educational process, including ones based on religion, the environment, technology, and globalisation are taken into account (Susilo, 2017b).

\section{Transactional}

In terms of the implementation of education, Muhammadiyah schools with a strong level of autonomy are able to develop a curriculum with characteristics of excellence, especially in Muhammadiyah schools which have a curriculum based on tawheed. Tawhid-based curriculum is a process of managing teaching and learning activities centered on Islamic teachings and laws. The implementation of teaching and learning activities integrates values of Al-Islam and Kemuhammadiyahan in all its educational activities; develops specific learning 
methods, such as the bayani method or textual method (Fauzi, 2017; Iksan and Saufian, 2017); uses qur'ani or contextual methods (Andayani et al., 2017; Umaya et al. 2017); irfani (Kusuma, 2018); has strong funding sources; and has a productive BUMS (school-owned enterprise).

In addition, schools also have very high interest in enrolment, have a large number of study group, and have academic and non-academic achievements both nationally and internationally by all school members residents (principals, teachers, students, and administrative staff). According to Caldwell $(2014$, p. 14), that based on the results of Jensen's research, it can be concluded that learning strategies have an impact on student achievement and student achievement supported by the level of independence of the facilities provided by the school (procurement of facilities does not depend on donors), and student achievement is also supported by school leaders who have the flexibility to make policies.

On the other hand, schools with a strong level of autonomy show a lack of innovation in curriculum development and the use of learning methods. In addition, applicants in the medium category, have a limited number of study groups, academic achievements and non-academic achievements have not been up to the international level by all school member (principals, teachers, students, and administrative staff).

In fact, Muhammadiyah school autonomy in Sleman Regency integrates school-based persyarikatan (SBP) with school-based management (SBM) models (Caldwell, 2016:3) with the aim of improving their quality. Several large and independent schools are applying the integration by implementing Muhammadiyah-based quality improvement management (MPMBSM). Muhammadiyah schools that are managed in such a way show good results, it is proven that they are in great demand by the community with new student admissions that always exceed the number of admissions. In addition, the existence of a student pick-up strategy, the use of school buses at SMP Muhammadiyah 1 Minggir can increase student interest in studying at this school. This attractiveness can be demonstrated by the school having seven study groups per generation, while other schools still have a shortage of students. SMP Muhammadiyah 3 Depok also has excellent programmes in the form of networks abroad to be able to make achievements at the national and even international level. SMP Muhammadiyah 1 Gamping provides life skills for its students in the form of compulsory extracurriculars, while SMP Muhammadiyah 1 Kalasan provides skills for students with moral education and national education during the implementation of curricular programs at the beginning and end of lessons (Susilo, 2017b).

Concrete manifestations of school autonomy efforts are also reflected in enrolment interest using the 'place message' system (following initial enrolment, while waiting for school graduation), in addition to high community expectations and beliefs about guaranteed childhood education in schools of interest, achievement, affordable costs, and completeness of facilities.

Through the discussion above, it can be seen that average Muhammadiyah schools have a strategy to realise their independence. The existence of Muhammadiyah school independence can be evident from learning implementation that reflects the vision of its mission; the launch of flagship programmes; extracurricular activities as a distributor of students' talents and interests; the implementation of Al-Islam and Kemuhammadiyahan; and the achievements of both teachers and students as a form of high school competitiveness.

The autonomy of Muhammadiyah schools can be established by: 1) changing the direction of the policy of progress; 2) building strong leadership; 3 ) creating a prosperous culture; and 4) strengthening school networks (Susilo, 2017d). On the other hand, standards of Muhammadiyah school autonomy should to be able to produce high quality graduates with the following qualifications: (1) performing regular prayers (Al-Islam); (2) being literate in Al-Qur'an; (3) displaying good nationalism; (4) having high academic achievement; 5) mastering a foreign language; and (6) being literate in IT (Susilo 2016, 2017c).

\section{CONCLUSION}

Based on the study results, it can be concluded that SMP Muhammadiyah 1 Gamping has an autonomy score of 365.30 in the strong category; SMP Muhammadiyah 1 Minggir has an autonomy score of 394.58 in the very strong category; SMP Muhammadiyah 2 Kalasan has an autonomy score of 354.56 in the strong category; and SMP Muhammadiyah 3 Depok has an autonomy score of 364.66 in the strong category. Therefore, it can be concluded that the four schools have strong or very strong autonomy, as is evident from the branding of each school, their outstanding achievements, a school culture that has been ingrained in the heart of the school community, and high public interest. 


\section{REFERENCES}

Andayani, Endah, Lilik Srihariani, Suko Winarsih, and Rusno Rusno. 2017. "The Contribution of School's Characters to the Effectiveness of Entrepreneurial Learning Based on Local Wisdom." IJPTE : International Journal of Pedagogy and Teacher Education 1(1):37-45.

Bangka Pos. 2017. "Program Unggulan Di Sd Muhammadiyah, Siswa Harus Hafal Alquran [Excellent Program at Muhammadiyah Elementary School, Students Must Memorize the Qur'an]." Bangkapos.Com. Retrieved April 5, 2018 (http://bangka.tribunnews.com/2017/07/17/program-unggulan-di-sd-muhammadiyahsiswa-harus-hafal-alquran).

Caldwell, Brian John. 2016. Impact of School Autonomy on Student Achievementin 21st Century Education: A Review of the Evidence. Melbourne: A contribution to the International Study on School Autonomy and learning (ISSAL), Educational Transformations.

Cheng, Y. C., and W. T. Ming. 1997. "Multi-Models of Quality in Education." Quality Assurance in Eduation 5.

Department of Education and Skills. 2015. Advancing School Autonomy in the Irish School System: Research Paper. Ireland: Department of Education and Skills.

Eurydice. 2007. School Autonomy in Europe Police and Measures. Belgium: the Eurydice European Unit.

Fauzi, Adin. 2017. "The Effect of Edmodo on Students' Writing Skill in Recount Text." IJPTE : International Journal of Pedagogy and Teacher Education 1(2):73-79.

Fulton County Schools. 2014. School Autonomy Guidebook 2014-2015: Fulton County Schools Where Students Come First. 2nd ed. Georgia: Fulton County Schools.

Hamilton Associates. 2015. School Autonomy: Building the Conditions for Student Success. Western.

Hargreaves, A. 1995. Changing Teachers, Changing Times. Teachers' Work and Culture in the Postmodern Age. Professional Development and Practice Series. New York: Teacher College Press.

Harris, A. 2005. School Improvement: What's in It for Schools? London and Ner York: RoutiedgeFalmer.

Iksan, Zanaton H., and Sumaiyah Mohd Saufian. 2017. "Mobile Learning: Innovation in Teaching and Learning Using Telegram." IJPTE : International Journal of Pedagogy and Teacher Education 1(1):19-26.

Irianto, Yoyon Bahtiar. 2015. Modul 5 Pemasaran Pendidikan [Module 5 Marketing Education]. Bandung: UPI.

Kabargersik.com. 2017. "Sekolah Muhammadiyah Harus Mandiri [Muhammadiyah Schools Must Be Independent]." Kabargersik.Com. Retrieved April 5, 2018 (http://www.kabargresik.com/sekolahmuhammadiyah-harus-mandiri/).

Kusuma, Wira Hadi. 2018. “Epistemologi Bayani, Irfani Dan Burhani Al-Jabiri Dan Relevansinya Bagi Studi Agama Untuk Resolusi Konflik Dan Peacebuilding [Epistemology of Bayani, Irfani and Burhani Al-Jabiri and Their Relevance for Religious Studies for Conflict Resolution and Peacebuilding]." Syi'ar 1(Januari-Juni):1-19.

Lusiana, Vera. 2015. "Muhammadiyah Klaim Mandiri Dalam Pendanaan Semua Kegiatan [Muhammadiyah Claims to Be Independent in Funding All Activities]." Antarariau.Com. Retrieved April 5, 2018 (https://www.antarariau.com/berita/65595/muhammadiyah-klaim-mandiri-dalam-pendanaan-semuakegiatan).

MacNeil, Angus J., Doris L. Prater, and Steve Busch. 2009. "The Effects of School Culture and Climate on Student Achievement." International Journal of Leadership in Education 12(1):73-84.

MC Provinsi Jawa Timur. 2018. "Muhammadiyah Wilayah Jatim Buat Program Sekolah Tangguh Bencana [Muhammadiyah in East Java for Disaster-Resilient School Program ]." Infopublik.ld. Retrieved April 5, 2018 (http://infopublik.id/read/251129/muhammadiyah-wilayah-jatim-buat-program-sekolah-tangguhbencana.html).

Muhammadiyah Yogyakarta Regional Leadership Council for Primary and Secondary Education. 2015. Kumpulan Peraturan/Ketentuan: Di Lingkungan Pendidikan Dasar Dan Menengah PWM Di Yogyakarta [Set of Rules/Regulations: In the PWM Primary and Secondary Education Environment in Yogyakarta]. Yogyakarta: Muhammadiyah Yogyakarta Regional Leadership Council for Primary and Secondary Education.

Musdani, Akhmad. 2017. "Smp Muhammadiyah Kutoarjo Siapkan Siswa Mandiri Dan Berakhlaq Islami [SMP Muhammadiyah Kutoarjo Prepares Students to Be Independent and Have Islamic Character]." Muhammadiyah Central Leadership. Retrieved April 5, 2018 (http://m.muhammadiyah.or.id/id/news12150-detail-smp-muhammadiyah-kutoarjo-siapkan-siswa-mandiri-dan-berakhlaq-islami.html).

Nursalikah, Ani, and Citra Listya Rini. 2013. "Kiprah Panjang Muhammadiyah Di Dunia Pendidikan [Muhammadiyah's Long Journey in the World of Education]." Republika Online. Retrieved April 5, 2018 (http://khazanah.republika.co.id/berita/dunia-islam/islam-nusantara/13/06/12/moae7p-ahok-pernah- 
mengenyam-pendidikan-di-sekolah-muhammadiyah).

OEDC. 2014. Lesson from PISA for Korea: Strong Performance and Successful Reformers in Education. Korea: OEDC Publishing.

Ratnawati, Dian. 2016. "Momen Idul Adha Sekolah Muhammadiyah plus, Cetak Mubaligh Hafiz, Alim Dan Mandiri [The Moment of Eid Al-Adha at the Muhammadiyah School plus, Prints Hafiz Preachers, Pious and Independent]." Hangtuahnews.Co.Id. Retrieved April 5, 2018 (https://hangtuahnews.co.id/momen-iduladha-sekolah-muhammadiyah-plus-cetak-mubaligh-hafiz-alim-dan-mandiri/).

Rukmana, Yulis. 2016. “Momen Idul Adha Sekolah Muhammadiyah plus, Cetak Mubaligh Hafiz, Alim Dan Mandiri [Strategies to Build a Brand Image in Increasing the Competitiveness of Educational Institutions: A MultiCase Study at SMA N 3 Malang and SMA Nurul Jadid Paiton Probolinggo." Universitas Islam Negeri Maulana Malik Ibrahim Malang.

Scileanna, Agus. 2015. Advancing School Autonomy in the Irish School System. Oideachais.

SD Muhammadiyah Sapen. 2017. "Sapen Launching 'Sapen Boga Mandiri'[Sapen Launching 'Independent Catering Sapen']." Muhammadiyah Sapen Elementary School. Retrieved April 5, 2018 (http://www.sdmuhsapen-yog.sch.id/read/583/sapen-launching-sapen-boga-mandiri.html).

SMP Muhammadiyah 2 Surabaya. 2018. "Sunday School." Smpmudasby.Sch.ld. Retrieved April 5, 2018 (http://smpmudasby.sch.id/sunday-school/).

Solopos. 2017. "70\% Sekolah Muhammadiyah Di DIY Belum Mandiri [70\% of Muhammadiyah Schools in DIY Are Not Independent]." Ucnews.Id. Retrieved April 5, 2018 (https://www.ucnews.id/news/70-SekolahMuhammadiyah-di-DIY-Belum-Mandiri/577966598006734.html).

Suaramuhammadiyah.id. 2016. "MDMC Kukuhkan Smp Muhammadiyah 1 Prambanan Sebagai Sekolah Siaga Bencana Mandiri. Suara Muhammadiyah [MDMC Confirms SMP Muhammadiyah 1 Prambanan as an Independent Disaster Prepared School]." Suara Muhammadiyah. Retrieved April 5, 2018 (http://www.suaramuhammadiyah.id/2016/12/18/mdmc-kukuhkan-smp-muhammadiyah-1-prambanansebagai-sekolah-siaga-bencana-mandiri/).

Susilo, M. Joko. 2016. "Study of School Independence in Muhammadiyah Charities." Pp. 625-33 in Proceedings of the National Seminar on Sustainable and Exciting Education. Medan: Cooperation with the Association of Higher Education Teacher Training and Education Institutions, Mughammadiyah Educational Council, Research and Development Board of Muhammadiyah Central Leadership, Muhammadiyah University of Surakarta, University of Nor.

Susilo, M. Joko. 2017a. Buku Panduan Kemandirian Sekolah Muhammadiyah Kemandirian [Self-Reliance Guide Book for Muhammadiyah Schools of Self-Reliance]. Yogyakarta: UNY.

Susilo, M. Joko. 2017b. "Kajian Kemandirian Sekolah Di Amal Usaha Muhammadiyah [Development of an Evaluation Model for the Independence of Muhammadiyah Schools in Sleman Regency]." Yogyakarta State University.

Susilo, M. Joko. 2017c. "Leadership Model in Muhammadiyah to Create Independence School." Pp. 125-31 in Proceedings of International Symposium on the Transition from School to Work. Yogyakarta: Yogyakarta State University, Indonesia in collaboration with Curtin University Australia.

Susilo, M. Joko. 2017d. "Strategi Membangun Sekolah Yang Berkemandirian [Strategies to Build an Independent School]." Pp. 569-76 in Second Progressive and Fun Education Seminar. Lombok: Asosiasi Program Studi Pendidikan Biologi.

Triwiyanto, Teguh. 2015. "Membangun Citra Sekolah [Build the Image of the School]." School Based Management. Retrieved April 1, 2018 (http://mbscenter.or.id/site/page/id/390/page_action/viewdetail).

Umaya, Nazla Maharani, Sarwiji Suwandi, Budiyono Budiyono, and Andayani Andayani. 2017. "Local Stories Adapted as Learning Tools Innovation of Fairy Tale for Teacher to Improve the Literacy Skills of Student in Secondary Schools." IJPTE : International Journal of Pedagogy and Teacher Education 1(1):63-72.

Zamroni. 2016. Budaya Sekolah [School Culture]. Yogyakarta: Gavin Kalam Utama. 